\title{
University Students` Perception and Utilization of Technology for Learning: The Case of Haramaya University
}

\section{Sisay Awgichew Wondemtegegn, Haramaya University, Ethiopia}

\begin{abstract}
As technology has become more prevalent and accessible to students in their personal lives, learning experiences and interaction, it encouraged students to engage and generate innovative and creative ideas and sharing learning experiences. This paper examines university students` perceptions and utilization of technology for learning at Haramaya University in Ethiopia (as a case). The researcher used survey research design and questionnaire (students=298) as principal data collection instrument. The participant sampled using purposive, heterogeneity and systematic random sampling techniques. The collected data were analysed by descriptive (mean, percentage and frequency) and inferential statistics (t-test). Students` perception in relation to gender and their locality (rural and urban), and utilization of technology addressed by this study. The finding of the study revealed that there is no statistically significant mean difference between male and female students' perceptions towards technology utilization for learning $(\mathrm{t}(296)=\mathrm{t}-.102, \mathrm{p}>0.05, \mathrm{p}=0.919)$. This was the same for students who came from rural and urban areas $(\mathrm{t}(296)=\mathrm{t}=-.126, \mathrm{p}>0.05, \mathrm{p}=0.900)$ and students have positive perception towards technology assisted learning. The paper revealed that students have been using technology for educational purpose and face challenges.
\end{abstract}

Keywords: Technology Utilization for Learning; Students`Perception 


\section{Introduction}

Information and communication technology (ICT) encompasses the effective use of equipments and programs to access, retrieve, convert, store, organize, manipulate and present data and information (Gay \& Blands, R, 2005). Education is one the public sectors highly influenced by technological development (Kozman, 2005). Using information communication technology in higher education teaching and learning is a global phenomenon and the center of investment in various universities around the world (Selwyn, 2007). The increasing use of computer application and utilization in college education is likely to have important effect in teaching and learning of various subjects (Liu et al, 2010). Instructional technologists believe that utilizing technology in teaching and learning in classroom can greatly enhance the efficiency of students learning and academic achievements.

In higher learning institutions, ICT is dominantly used for distance instruction (Clegg et al, 2000, Hazemi et al, 2002 as cited in Christina et al, 2002) and it is not considers as new experience. In the 1980s online methodologies were developed to support campus-based and distance education, under the headings "computer-based or " computer-managed learning" e.g. bulletin board system, electronic mail and computer- mediated conferencing (William et al, 1999). In recent years utilizing technological tools such as graphics, videos, threedimensional objects, animation, audio-visual materials and e-video conferencing to support distance, and e-learning programs, accessing distinguished professors are prevalent across the world. E- Learning, which is described as the use of ICT to enhance or support learning and teaching in education, has become increasingly important in tertiary education (Adedeji, 2010).

Teachers in higher education institution use the combination of methods to teach different courses from the traditional lecturing methods that make students passive recipients to constructivist methods of teaching that recognizes the ability of students in constructing his/her own world. Recently, technology mediated teaching such as Projector, PowerPoint, Video, Internet, E-learning and teaching are familiar in academia education. Students use the Internet to visit websites of business and professional organizations cited in textbooks, conduct computer searches for academic and professional journals, prepare case studies and research papers, and use free online tutorials assistance, study guides with practice test, etc (Thomas L et al, 2009). The Internet also provides access to current events, news, and many 
other types of information since it is the largest library and laboratory and it becomes a popular tool for instruction. Furthermore, the students' use of technology in school and university today's will change the future employees' effectiveness and efficiency in using the different types of technology on jobs in the competitive world of work. Despite the essential role of technology in simplifying the live of human being technology may have negative effects, e.g., Cyber cheating, technology based cheating, plagiarism and information overload that resulted in less learning (Austin \& Brown, 1999, Rockwell \& Singleton, 2007 as cited in Thomas L et al, 2009).

Research findings regarding students' perception may have significant implication for university managements, faculty members, teachers, students and employers to enhance the delivering of education to students in higher learning institution and students`application of the experienced knowledge and skills in the real world of work. However, very small research has addressed students' perception and reaction to multimedia education, models and methodologies for the study of technology-assisted learning (Webster \& Hackley, 1997; Connel, 2006; Schmid, 2008, as cited in Thomas L et al, 2009). Therefore, the intention of this paper is to investigate university students' perception and utilization of ICT for learning purposes.

\section{Statement of the Problem}

The attitude and perception of teachers and students' towards educational technology may affect its implementation and utilization for teaching and learning processes and purposes. Researchers have shown that students' perceptions and their readiness to accept computer technology in teaching are critical to the success of their learning (Buabeng, A \& Yidana, I, 2015). According to Dorup (2004), students' preferred the use of ICT in learning and they showed positive attitudes towards the technology. However, the nature of classroom organization, classmates, teachers, availability of resources, could influence these positive attitudes (Kennewell, 2001). Several studies on students' attitudes towards ICT and their relationship with gender have revealed conflicting results. Kubiatko and Halakova (2009) conducted a study on high school students ' perception of using ICT in studying Biology. The result revealed that male students have more positive perception towards the use of ICT than female students do. Furthermore, the study of Papaioannous and Charalambous (2011) as cited in Buabeng, A \&Yidana, I, (2015) found out that male students had more positive 
attitudes towards ICT than their female counter part. Seyal, Rahim and Rahman (2002) study on computer attitudes of 268 students in contrary revealed that no significant differences in attitudes with regards to gender. In addition, Mizrachi and Shoham (2004) studied students' attitudes in schools. The study found no significances difference in attitudes concerning gender. This controversy not yet investigated in depth in African higher learning institution context. Furthermore, it would be progressively imperative to consider students perceptions of ICT and the way they use ICT in higher education institutions because they are the key stakeholders in the teaching and learning processes.

Notwithstanding, significant progresses in technological development, a number of important physical, cultural, social, economic and pedagogical factors hindering the use of ICT by teachers and students in sub-Saharan Africa, particularly in rural schools. These include lack of electricity and frequent power outages/shortage, poor technology infrastructure, connectivity problems, problem in software license and equipment maintenance, insufficient and inappropriate software penetration in the markets, non-competitive and government dominated telecommunication policies and regulations may impede connectivity and sustainability (Hawkins, 2002).

Educators have consistently made various assumptions about the relationships between technology utilization and students learning. Some scholars assumed that students who learn in classes where staff members frequently utilize technology in to instruction are likely to exhibit positive perceptions about computer technology and enhance their learning. Various researches' conducted about teachers' perception towards technology-assisted teaching (TAT), however, little attention has been giving to technology utilization for learning and perception of students towards it. Therefore, this study intended to examine the perception of students towards technology and utilization for learning purposes. For this research, the researcher considered technology as the combination of more than one media devices such as Internet, mobile, laptop, desktop computer, LCD projector and PowerPoint in an effort to investigate the perception of students towards technology utilization for learning. The researcher designed and answered the following basic questions:

a) To what extents do students` utilize technology for learning in Higher learning institution? 
b) Do differences exist across localities in students` perception towards utilization of technology for learning?

c) Is there a difference between male and female students perception in utilization of technology for learning?

d) What are the major challenges that may faced by students in utilization of technology for learning at Haramaya University?

\section{Objectives and Hypotheses of the Study}

The major objective of the study was to investigate university students' perception and utilization of ICT for learning in Haramaya University (as a case). To measure students' perception and utilization of ICT the following specific objectives are outlined:

a) To determine how far students utilize technology for learning at Haramaya University

b) To check he differences that exist across localities in students perception towards utilization of technology for learning

c) To check the difference between male and female students perception in utilization of technology for learning

d) To determine the challenges that may faced by students in utilization of technology for learning at Haramaya University

In order to measure these objectives, the following hypotheses were formulated to be tested.

\section{Hypotheses}

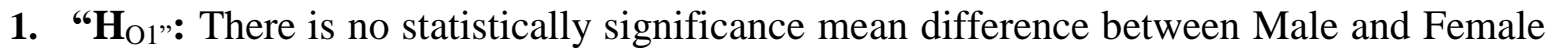
students' perception towards utilization of technology for learning.

2. " $\mathrm{H}_{\mathrm{O} 2 "}$ " There is no statistically significance mean difference between students' perception towards utilization of technology for learning based on their locality (Rural \&Urban)

\section{Review of Related Literature}

Computer assisted learning can play both a supplantive role and supportive role (Huczynski and Johnston, 2005; Sangster, 1992 as cited in Belal, 2011). In a supplantive role, CAL 
replaces the lecturer/tutor. On the other hand, in a supportive role it does not substitute the lecturer/tutor rather it gives an opportunity for practice, for self-assessment, and to reinforce the points made by the lecturer/tutor. The need to incorporate technology in to curriculum has been recognised for many years in different parts of the world. According to Miranda and Russell (2011), "Since the early 1990s, schools, districts, and the federal government have invested heavily in instructional technology (IT). Teacher and student access to technology in school has improved dramatically.

According to UNESCO (2004), there are three main approaches to use ICT by teachers. The first one is an integrated approach meaning (planning the use of ICT within the subject to enhance particular concepts and skills and improve students' attainments). The second is an enhancement approaches (planning the use of ICT resources that will enhance the existing topics through some aspect of the lessons and tasks) and the third is a complementary approach (using ICT resources to empower the pupils` learning). All the three approaches can enhance attainment, but the effects may be different. In the integrated approach, students learning enhanced because they are confronted with challenges to their existing knowledge and given deeper insights in to the subject being studied. The enhancement approach presents knowledge in new ways; encouraging learners too formulate their own explanations. The complementary approach frees the learner to focuses on more challenging subject-focused tasks.

It has been believed that ICT has very strong effect in education. There are many studies that are recognised the role of technology in facilitating the interaction between students-students, students- materials, students-teachers, accessing both personal and educational information. ICT can have a useful effect on teaching and learning if it`s utilized properly under the right condition including proper training, resources, support and perception. It also offers the potential to met the learning needs of individual students, to promote equal opportunities', to offers learning materials, and promote positive interdependence of learning among learners (Cavas, 2009). The impact of ICT on the learning process seems to be more important and requires more that looking only to the curricula. Improved students outcomes are observed with regard to motivation, enjoying learning, self-esteem, ICT skills, collaborative skills, subject knowledge, information handling skills, meta-cognitive skills, etc. (Yousaf, 2008 as cited in Azhar et al, 2011). 


\section{Existing ICT status in Ethiopian}

The world has witnessed an unprecedented increase in access to information and communication technologies (ICT). Nowadays ICT is increasingly used as a key enabler and transformational tool to foster economic growth, accelerate knowledge transfer, develop local capacities, and raised productivity in a variety of sectors, in both developed and developing countries. The government of Ethiopia has embarked on an ICT enabled transformation journey, aiming to enhance their efficiency across sectors (Marc \& Mariana, 2014). Ethiopian is among the poorest with the quality of telecom infrastructure and service in Africa (Marc \& Mariana, 2014), to change the situation the government of Ethiopia has taken decisive steps towards advancing the country from a low mobile, Internet, and broadband penetration rates to a highly connected society. By signing a two-year management contract (2010-2012) with France Telecom, the state-owned Ethiopian Telecom Company (ETC) took further step towards changing course and transforming the telecom landscape in Ethiopia. Within this period the operators serves 20 million customers as of December 2012, with 50\% growth. Moreover, Ethiopia Telecom has recently introduced a range of service to extended national and international service. The public operator is rehabilitated its optical fiber network (more than $10,000 \mathrm{~km}$ ) and other service. These have been achieved in partnership with the Chinese manufacturing ZTE who signed a US \$1.5 billion contract in 2010 to provide telecom equipment to Ethiopia (Marc \& Mariana, 2014).

In Ethiopia, huge investment has been made to acquire the latest technology and expand the service in the telecom sector. As a result, accessibility and quality of telecommunication service have improved the number of customers of all kinds of telecom service increased from 7.7 million by $2009 / 10$ to 39.8 million by 2014/15. During the same period, the number of mobile subscription increased from 6.7 million in 2009/10 to 38.8 million by 2014/15 (GTP-II-). The share of rural "kebeles" with access to telecom service (with $5 \mathrm{~km}$ radius) increased to $97 \%$ by $2014 / 15$ from $62.1 \%$ in $2009 / 10$. The other significant achievement in the telecom sector, during GTP-I- period, is the introduction of $3.75 \mathrm{G}$ and $4 \mathrm{~g}$ internet networks with the capacity to provide services to 60 million customers. The government recognized wider application of e-government, e-commerce, e- learning, e-library, mobile banking and others have enabled to improve the quality and efficiency of public and private services. 
The government of Ethiopia clearly recognized the indispensible role of ICT to enabling the education sector and makes grate leaps forward and deliver the responsibilities of higher learning institutions that are quality teaching -learning, problem-solving research and community service (MoE, 2012). The understanding and commitment of university community to develop and use ICT as a solution to the various resources and manpower shortages that may prevent the education sector from delivering quality education, addressing the growing students population needs, introducing innovative teaching and conducting problem solving research is critical. However, ICT in the university has not made significant progress that as expected of it, nor has it delivered the several benefits that it should be deliver. Looking at the key role that ICT can and should play required that efforts have to be redoubled to move it forward so that it can pay back on the investment made on it, and play the role of turbo charging the education sector (MoE, 2012). The Ethiopian Federal Ministry of education designed proposal for university ICT organization in 2012 to reduce challenges that ICT face and considering ICT as an engine for rapid advance in the primary function of Ethiopian university MoE (2012).

The ICT directorate is responsible and accountable to the university presidents and member of the university top management council. The major role and responsibility of the directorate are providing leadership and management to the ICT department; insure that ICT provides, operates and maintains the ICT infrastructure, systems and solution to meet the needs of the administrative, educational, research program of the university; establish proper ICT governance through an ICT policy for the university, planning of ICT projects, managing the portfolio of solutions, system and infrastructure; and instituting service management approach to the service and solution that the ICT delivery to the university community; be an ICT evangelist in the university and its department; keep up with the ever changing ICT; and insure that the ICT department understand the need of its customer MoE (2012). The structural organization demonstrated as follows: 


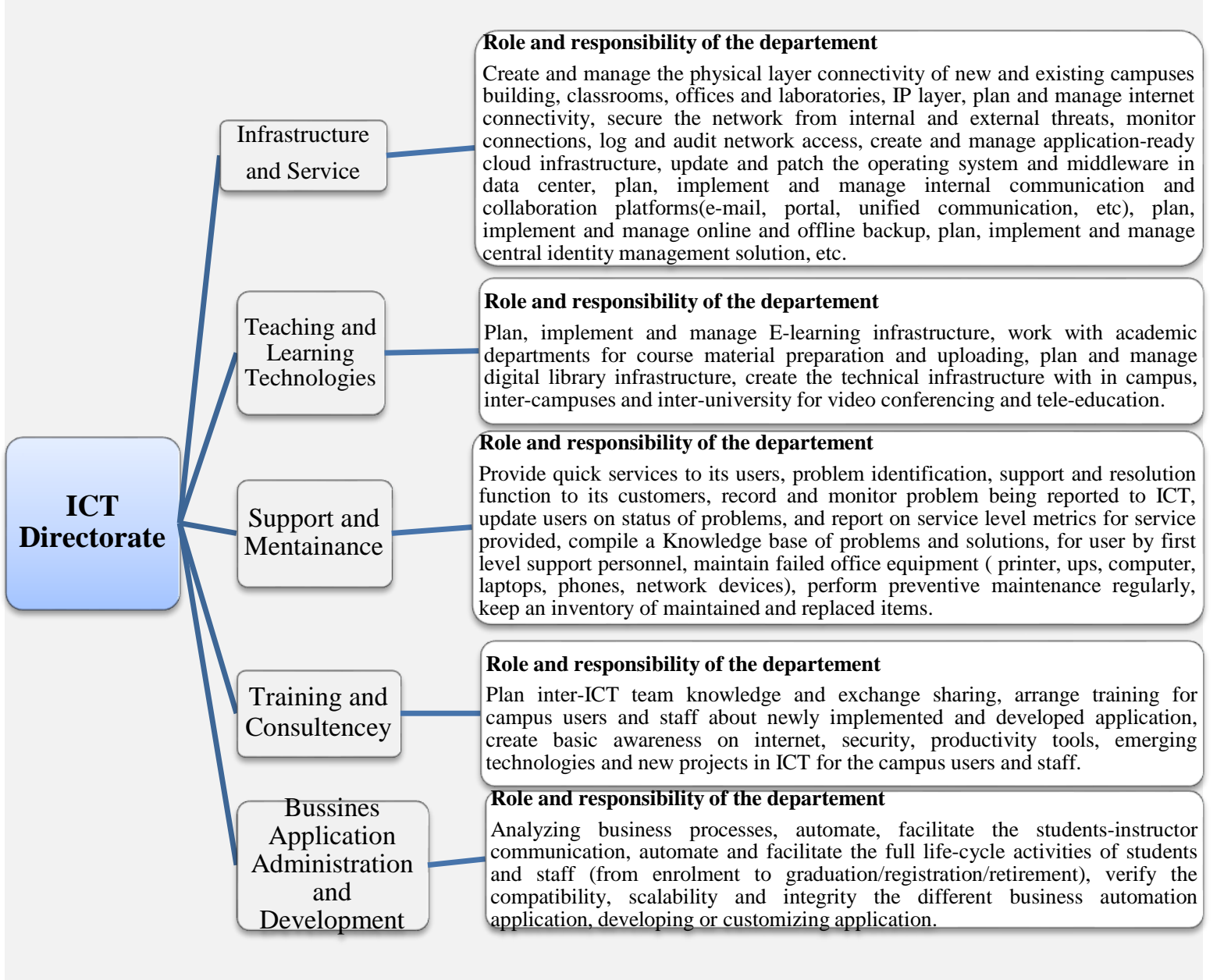

Diagram 1. ICT structure in Ethiopian Higher learning Institutions

\section{Research Design and Methods}

This study utilized a survey research design. A survey is an attempt to collect data from members of a population with respect to one or more variables (Gay, 2003). The goal of a survey is to gain specific information about a representative sample of a particular group, a self report measure is a strong method to provide great insight on an individual's perception. The researcher used gender and locality as independent variables, and perception of students as dependent variable. The sample for this study was derived from undergraduate students (graduating class of 2016/17) enrolled at Haramaya University (one of the oldest university in the country) some selected colleges. Both primary source of data (questionnaire and interview) and secondary source of data (document review) used to collect valuable information for the study. 
The total population of graduating class students was 1357 of which the researcher selected 310 students using Slovin Formula $\left(n=N / 1+N\left(e^{2}\right)\right.$ from four colleges. Systematic, purposive and heterogeneity-sampling techniques employed and equal representations were secured to select sample students across the colleges. The quantitative data substantiated by open-ended question items, interview data and document review related with ICT in Ethiopia. The number of items on the questionnaire were 52 and the reliability of the items were tested and the value of the reliability was $\alpha=0.832$ which is strongly acceptable. The Likert-type scale from 1-5 (5= "strongly agree", 4= "agree", 3= "undecided", 2= "disagree" and $1=$ "strongly disagree") was used to check students perception towards technology utilization for learning. Their level of practice measured on a scale of 1-5 score (5= "frequently", 4= "always", 3= "sometime", 2= "rarely" and 1= "not at all/never"). The data was coded and prepared using the Statistical Package for Social Sciences (SPSS 16) for analysis. Both descriptive and inferential statistics were used to calculate and report the result. Frequency, mean, standard deviation and independent sample t-test used to analyze the data.

\section{Data Presentation, Analysis and Interpretation}

This part of the piece of writing deals with the presentation, analysis and interpretation of the data gathered through survey questionnaire, interview and document review followed by discussion of the findings. Furthermore, the main findings of the study presented with the help of descriptive and inferential statistics. The researcher was distributed 310 questionnaires for sample respondents among them 298 (96.12\%) were filled the questionnaire and returned successfully. Therefore, the analysis depends on the information provided by these respondents.

Fig. 1 Background and other Basic Information

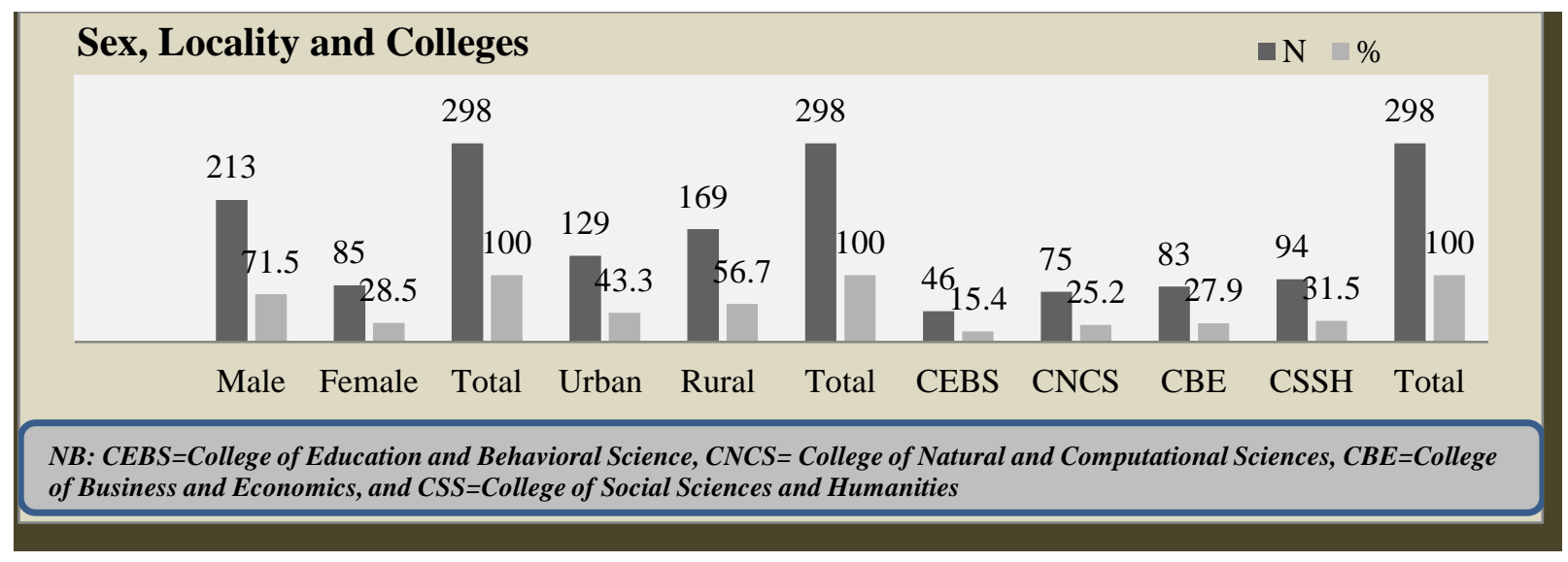


As it can be seen in the above Fig1, 213 (71.5\%) of respondents are male and the remaining 85 (28.5) are female students. Out of these 129 (43.3\%) are came from urban area and the remaining 169 (56.7\%) from rural area. From this data, we can understand that gender disparity is high in higher learning institutions. Regarding the composition of respondents 46 (15.4\%), 75(25.2\%), 83(27.9\%) and $94(31.5 \%)$ of respondents were selected from CEBS,

CNCS, CBE and CSSH respectively.

Fig. 2. Students Social Media Usage

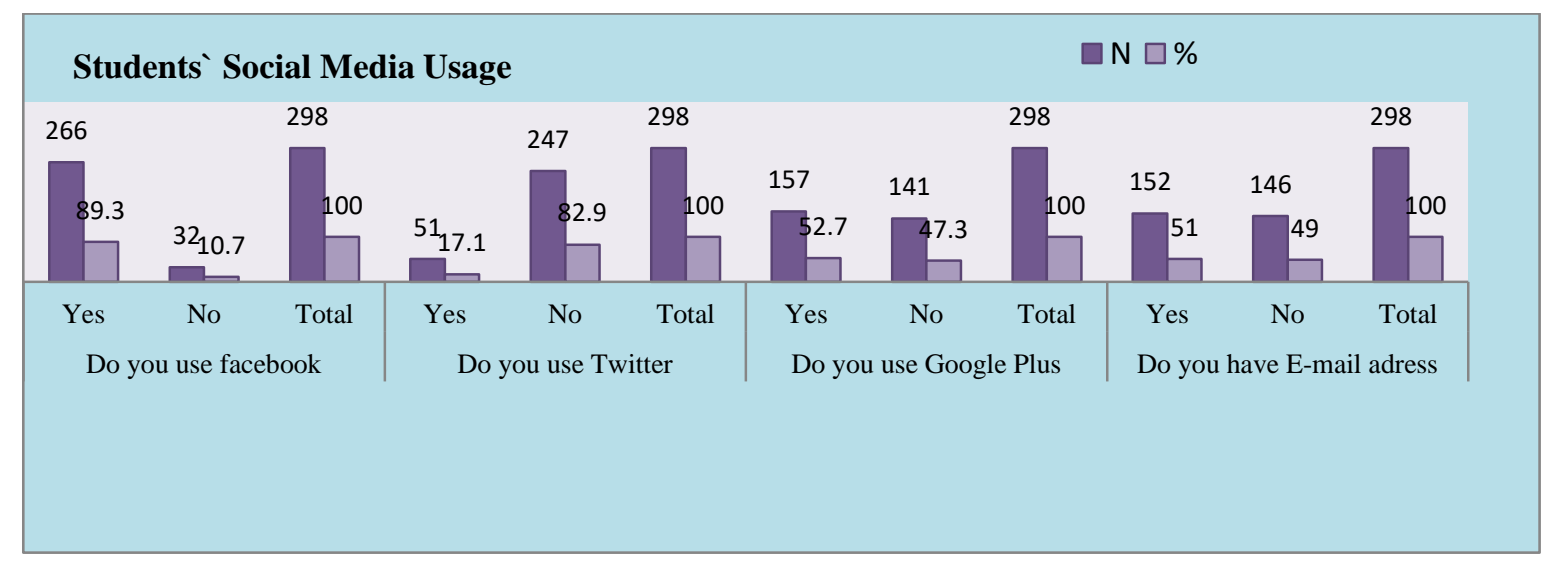

As shown in Fig. 2, $266(89.3 \%)$ of students respondents use facebook dominantly for personal and informational purposes than educational purposes, the remaining 32(10.7\%) of respondents do not use Facebook at all. In contrary 247(82.9\%) of students do not use twitter. Nearly half of respondents were use Google Plus and have E-mail address. Furthermore, students use "Viber", "Messenger", "Whatups" and "imo" to exchange message and personal information. Students' social media usage is growing in Africa.

Fig. 3. Issue related with students` thinking and training

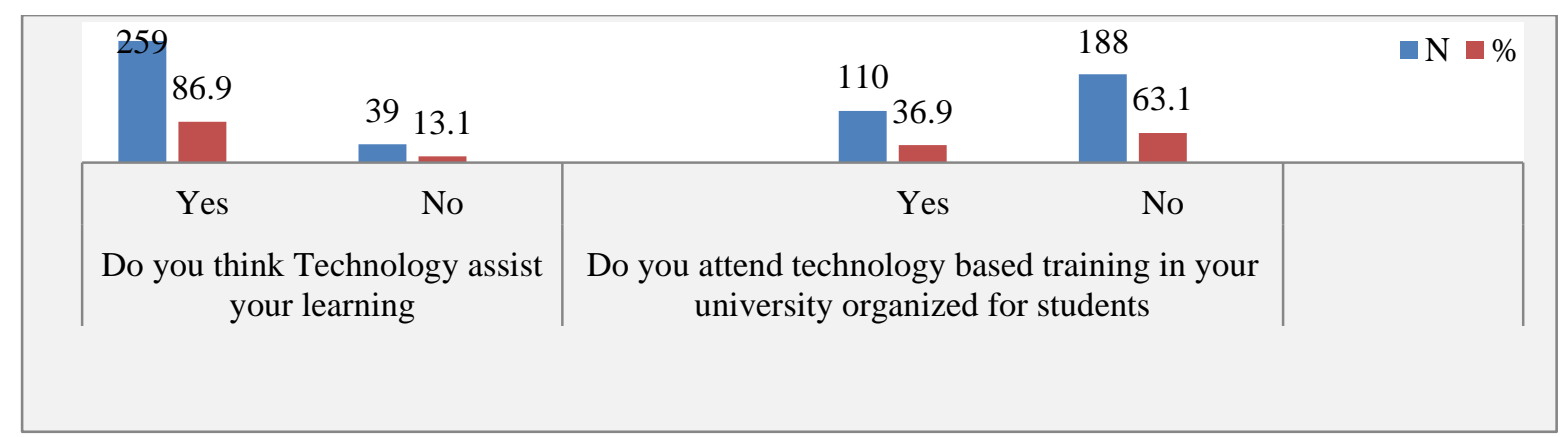


As it can be seen in the fig. 3, majority 259 (86.9\%) of respondents believe that technology can assist their learning. This may helps the university management and faculty members to facilitate the integration and utilization of information communication technology in teaching learning processes. It also helps the process of transformation of creating highly connected society. Nevertheless, no more than $110(36.9 \%)$ of students get support and training from the university the remaining $188(63.1 \%)$ of respondents did not get technology based training organized by the university for students. Therefore, the university management need to take the initiatives, colleges in collaboration with ICT directorate should organize training for both students and lecturers to enhance the integration and utilization of technology for learning.

Fig. 4. Issues related with frequency of Internet usage and support

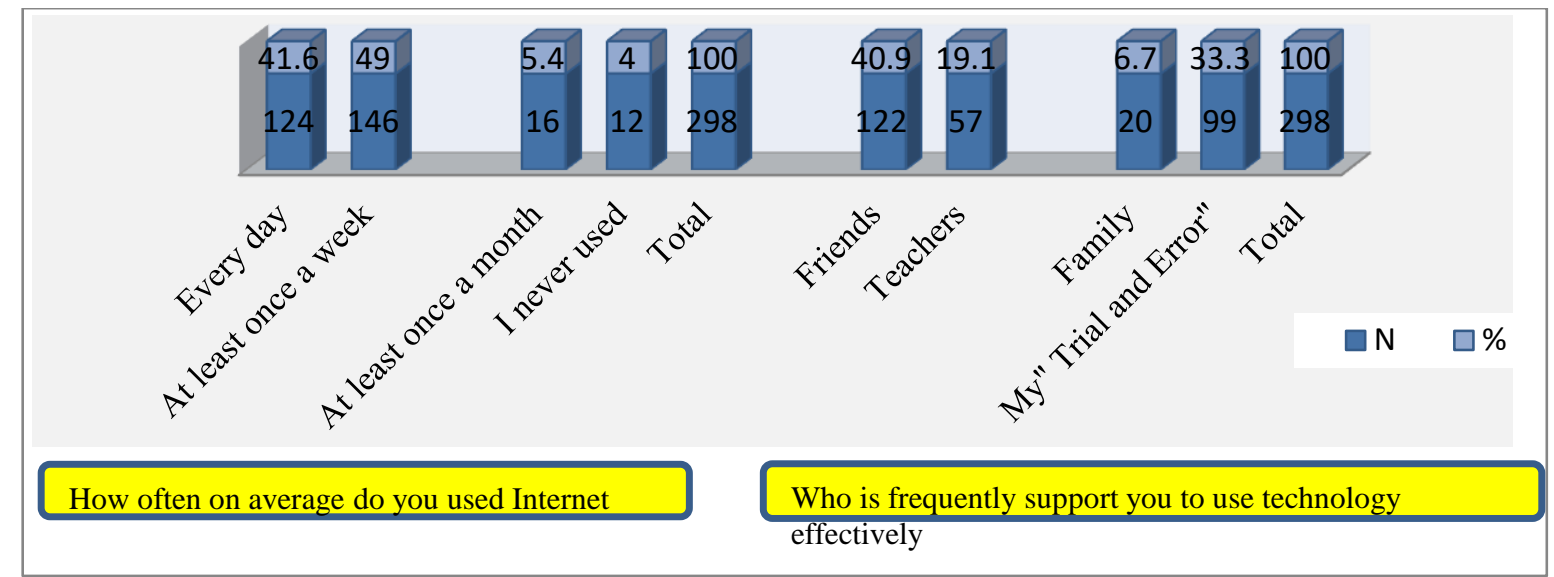

As the data obtained from respondents portray, majority 146 (49.0\%) of students use internet at least once a week, $124(41.6 \%)$ use internet every day, the remaining 16 (5.4\%) use at least once a month and $12(4.0 \%)$ of respondents never used internet. Interestingly, 122 (40.9\%) of respondents get support from their friends, 99 (33.3\%) of respondents use technology by "trial and Error", the remaining 57 (19.1\%) get support from teachers and 20 (6.7\%) from their family. From this data, we can understand that the students' cooperative and collaborative learning, personal experiences and practice enhance students understanding about technology. 
Table 1. Respondents Perception towards Technology utilization for Learning

\begin{tabular}{|c|c|c|c|c|c|c|c|c|}
\hline Items & Sex & $\mathrm{N}$ & Mean & SD & Locality & $\mathrm{N}$ & Mean & SD \\
\hline \multirow{2}{*}{$\begin{array}{l}\text { I feel that Technologies can help me to increase my } \\
\text { knowledge in my subject }\end{array}$} & $\mathrm{M}$ & 213 & 4.46 & .803 & Urban & 129 & 4.58 & .681 \\
\hline & $\mathrm{F}$ & 85 & 4.53 & .700 & Rural & 169 & 4.40 & .833 \\
\hline \multirow{2}{*}{$\begin{array}{l}\text { I feel that Technology can have a room for different } \\
\text { learning styles }\end{array}$} & $\mathrm{M}$ & 213 & 4.21 & 1.613 & Urban & 129 & 4.12 & .924 \\
\hline & $\mathrm{F}$ & 85 & 4.00 & .859 & Rural & 169 & 4.18 & 1.737 \\
\hline \multirow{2}{*}{$\begin{array}{l}\text { I feel that I am successful in learning through } \\
\text { technology }\end{array}$} & $\mathrm{M}$ & 213 & 3.73 & 1.217 & Urban & 129 & 3.79 & 1.229 \\
\hline & $\mathrm{F}$ & 85 & 4.04 & 1.063 & Rural & 169 & 3.84 & 1.146 \\
\hline \multirow{2}{*}{$\begin{array}{l}\text { I perceive that Technology can help me to maximize } \\
\text { my Technical Skills }\end{array}$} & $\mathrm{M}$ & 213 & 4.17 & 1.034 & Urban & 129 & 4.26 & .871 \\
\hline & $\mathrm{F}$ & 85 & 4.34 & .765 & Rural & 169 & 4.19 & 1.035 \\
\hline \multirow{2}{*}{$\begin{array}{l}\text { I perceive that Technology can help me to maximize } \\
\text { my Academic Achievement }\end{array}$} & $\mathrm{M}$ & 213 & 4.06 & 1.047 & Urban & 129 & 4.03 & 1.053 \\
\hline & $\mathrm{F}$ & 85 & 4.11 & .951 & Rural & 169 & 4.11 & .994 \\
\hline \multirow{2}{*}{$\begin{array}{l}\text { I perceive that Technology can help me to maximize } \\
\text { my social interaction/relation }\end{array}$} & $\mathrm{M}$ & 213 & 4.17 & 1.041 & Urban & 129 & 4.10 & 1.014 \\
\hline & $\mathrm{F}$ & 85 & 3.95 & 1.101 & Rural & 169 & 4.11 & 1.099 \\
\hline \multirow{2}{*}{$\begin{array}{l}\text { I perceive that Technology can help me to maximize } \\
\text { my deeper understand in learning }\end{array}$} & $\mathrm{M}$ & 213 & 4.07 & .979 & Urban & 129 & 4.09 & .936 \\
\hline & $\mathrm{F}$ & 85 & 4.05 & .950 & Rural & 169 & 4.04 & .996 \\
\hline \multirow{2}{*}{$\begin{array}{l}\text { I feel that Technology can helpfully support my } \\
\text { experience of reading books }\end{array}$} & $\mathrm{M}$ & 213 & 4.08 & 1.047 & Urban & 129 & 4.05 & .951 \\
\hline & $\mathrm{F}$ & 85 & 4.02 & .926 & Rural & 169 & 4.08 & 1.060 \\
\hline \multirow{2}{*}{$\begin{array}{l}\text { I feel that Technology make my learning easy and } \\
\text { simple }\end{array}$} & $\mathrm{M}$ & 213 & 4.11 & 1.110 & Urban & 129 & 4.02 & 1.228 \\
\hline & $\mathrm{F}$ & 85 & 4.11 & 1.091 & Rural & 169 & 4.18 & .996 \\
\hline
\end{tabular}

Note: the mean score ranged from 1-1.5= strongly disagree, 1.51-2.5=Disagree, 2.51-3.5= undecided, 3.51-4.5=Agree and $>4.51=$ strongly agree .

As it can be seen in table 1, the mean score of the respondents to almost all the items is greater than 4.0, which indicates that mean score of students perception on utilization of technology for learning it is higher than the average (3.00). This means that students' perception towards technology utilization is positive. They perceived that technology could help them to increase their knowledge, learning successes, technical skills, academic achievements, social interaction, deeper understanding and make learning easy and simple. However, it doesn ' $t$ ' tell as whether the mean score are significant or not. Therefore, to check the statistical significance, independent sample t-test was computed and the result is shown in table 2 below.

Table 2. Computed independent sample t-test of students' perception

\begin{tabular}{lllllcc}
\hline Sex & N & Mean & Std. D & df & t & Sig. (2-tailed) \\
Male & 213 & 37.0657 & 6.09248 & & & .919 \\
Female & 85 & 37.1412 & 4.92842 & 296 & - & \\
& & & & &
\end{tabular}




\begin{tabular}{llllrrr}
\hline Urban Area & 129 & 37.0388 & 5.55428 & 296 & -102 & .900 \\
Rural Area & 169 & 37.1243 & 5.95638 & & .126 & \\
\hline
\end{tabular}

If $p<0.05$ (i.e. the significance level calculated is less than or equal to 0.05) then we would conclude that there is sufficient evidence to reject the null-hypothesis and thus accept the alternative hypothesis. If $p>0.05$ (i.e. is greater than 0.05) then we would conclude that there is not sufficient evidence to reject the null-hypothesis

Table 2 above portrays that there is no statistically significance mean difference between male and female students' perception towards technology utilization for learning $\mathrm{t}(296)=\mathrm{t}$ .102, $\mathrm{p}>0.05, \mathrm{p}=0.919$. Similarly, Seyal, Rahim and Rahman (2002) study on computer attitudes of 268 students revealed that there is no significance difference in students' attitude in relation to gender. In addition, Mizrachi and Shoham (2004) studied students computer attitudes in schools and found that there is no significant difference in attitudes concerning gender. However, more computer use leads to more positive computer attitudes.

Similarly, as can be seen from table 2 above there is no statistically significance mean difference between students' perception towards technology utilization for learning based on their locality (Rural \&Urban) t $(296)=\mathrm{t}=-.126, \mathrm{p}>0.05, \mathrm{p}=0.900$. This is may be the result of increased access to technology in Ethiopia. According to the government of Ethiopia the share of rural "Kebeles" with access to telecom service (with in $5 \mathrm{~km}$ radius) increased from $62.1 \%$ in $2009 / 10$ to $97 \%$ by $2014 / 15$ in (GTP-I-). Furthermore, in Ethiopia students start ICT education at the same grade level (grade $9^{\text {th }}$ ) in government schools both in rural and urban area.

Table 3. Issue related with Utilization of technology for learning

\begin{tabular}{ll|l|l|l|l}
\hline No Items & Sex & N & Mean & M. Difference \\
\hline 1. I use technologies that enhance my learning & $\mathrm{M}$ & 213 & 3.39 & -0.14 \\
\cline { 2 - 4 } & $\mathrm{F}$ & 85 & 3.53 & \\
\hline $\begin{array}{l}\text { 2. I use Mobile for doing assignment and read } \\
\text { learning content }\end{array}$ & $\mathrm{M}$ & 213 & 3.66 & -0.01 \\
\cline { 2 - 3 } & $\mathrm{F}$ & 85 & 3.67 & \\
\hline 3. I can learn lessons that appropriately combine & $\mathrm{M}$ & 213 & 3.06 & -0.38
\end{tabular}




\begin{tabular}{|c|c|c|c|c|}
\hline technologies & $\mathrm{F}$ & 85 & 3.44 & \\
\hline \multirow[t]{2}{*}{ 4. I like LCD projector and PowerPoint for learning } & $\mathrm{M}$ & 213 & 3.07 & \multirow[t]{2}{*}{-0.39} \\
\hline & $\mathrm{F}$ & 85 & 3.46 & \\
\hline \multirow{2}{*}{$\begin{array}{l}\text { 5. I use internet to do assignment and other learning } \\
\text { project }\end{array}$} & M & 213 & 3.68 & \multirow[t]{2}{*}{-0.17} \\
\hline & $\mathrm{F}$ & 85 & 3.85 & \\
\hline \multirow[t]{2}{*}{ 6. I use Face book for educational purpose } & $\mathrm{M}$ & 213 & 2.72 & \multirow[t]{2}{*}{-0.28} \\
\hline & $\mathrm{F}$ & 85 & 3.00 & \\
\hline \multirow[t]{2}{*}{ 7. I use Face book for informational purpose } & $\mathrm{M}$ & 213 & 3.76 & \multirow[t]{2}{*}{-0.15} \\
\hline & $\mathrm{F}$ & 85 & 3.91 & \\
\hline \multirow[t]{2}{*}{ 8. I use YouTube for educational } & $\mathrm{M}$ & 213 & 2.61 & \multirow[t]{2}{*}{-0.27} \\
\hline & $\mathrm{F}$ & 85 & 2.88 & \\
\hline \multirow{2}{*}{$\begin{array}{l}\text { 9. I use internet for Accessing and share educational } \\
\text { information }\end{array}$} & $\mathrm{M}$ & 213 & 3.13 & \multirow[t]{2}{*}{-0.19} \\
\hline & $\mathrm{F}$ & 85 & 3.32 & \\
\hline \multirow{2}{*}{$\begin{array}{l}\text { 10. I use online journals and digital storage to access } \\
\text { learning materials and books }\end{array}$} & $\mathrm{M}$ & 213 & 2.62 & \multirow[t]{2}{*}{-0.38} \\
\hline & $\mathrm{F}$ & 85 & 3.00 & \\
\hline Grand Mean & & & 3.388 & \\
\hline
\end{tabular}

Note: the mean score ranged from 1-1.5= "I cannot use at all", 1.51-2.5=" I can use rarely", 2.51-3.5= I can use sometimes", 3.51-4.5=" I can use always" and $>4.51=$ "I can use frequently".

As the above table depicted that university student sometimes, use technology that enhances their learning. Interestingly, from the table above we can comprehend that most of the university students use their mobile phone (smart phone) to do assignments and reading learning contents always the mean score of both sex were $>3.65$. Most of respondents like LCD projector, PowerPoint and can learn lesson that appropriately combines technologies.

Despite, Mobile penetration remains significantly below the regional average of sub-Saharan Africa of 53\% (Marc \& Mariana, 2014). They always use internet to do assignments and learning projects, (the mean score of male and female respondents on the issue was 3.68 and 3.84 respectively). Students of higher learning institution always use facebook for informational purposes. They use online journals and digital storage to access learning materials and books. They use mobile application for learning purposes. From the above 
mean difference we can understand that female students are better in using technology for learning than their male counterpart. The grand mean of all the above items is 3.388 meaning students sometimes utilized technology for learning purposes.

Most of respondents disclosed that, high coast of technological materials/devices; slow internet connection, lack of training, high cost internet service and lack of technical skills are the major challenges in utilization of technology in higher learning institutions. Furthermore, students as the challenges of technology utilization listed lack of organized laboratories, lack of support from top management, low experiences and inconsistent electric power supply. Likewise, Marc \& Mariana, (2014) in their studies stated that high telecommunication cost continue to hinder the country's competiveness for the sector. They also declared that poor qualities of infrastructure, weak institutional and regulatory framework, and low coverage of ICT service observed in Ethiopia

\section{Conclusion and Recommendation}

Some scholars in the field of educational and instructional technology promote the application of information communication technology, online learning environment, social media, internet technologies, and digitalized learning. However, there is a shortage of empirical research concerning students' perceptions regarding the use or utilization of technologies and technologies ability to promote learning. Therefore, this paper will contribute to the literature in the field.

The main conclusion of this study is that majority of university students believe that technology can assist their learning, and demonstrated positive perception towards technology utilization for learning. Based on the major finding we can conclude that there is no statistically significant mean deference between students` on their perception towards utilization of technology for learning against their gender and locality (rural \&urban). Furthermore, they feel that technology can help them to increase their knowledge, address different students learning style, maximize students' technical skills and academic achievements, deeper understanding, makes learning easy and simple. Students` use their mobile internet to access personal and educational information, doing assignments and learning new contents. 
However, specific factors have been identified as the challenges that affect utilization of technology for learning and teaching such as poor and slow internet connection, high price of internet service and technology materials, lack of awareness and support from faculty members and top management, lack of well-equipped ICT laboratory and inconsistent power supply. Optimistically, the result of this study may be seen just as the beginning of a transition processes to technology assisted teaching and learning in higher education. From the aforementioned findings, the researcher suggested that:

1) The university managements need to pay more attention to the use of ICT for teaching and learning in the university. They should maintain the growing ICT usage among students through continuous short and long-term ICT skill training and promotion of the benefits of ICT in education.

2) Higher learning institution management needs to make basic investments to advance access and utilization of technology with clear vision and strategies.

3) A lot needs to be done in order to create university net locally and join the rest of developed and modern universities in the world in the area of ICT to improve teaching learning and accessing educational information.

4) The government needs to allocate appropriate and independent budget for ICT infrastructural development for Higher learning institution and monitor the implementation.

5) The government of Ethiopia should improve infrastructural facilities like electricity, ICT materials, capacity of internet connection and services needs to be accessible at a very affordable price.

\section{Limitation of the Study}

The good news is that the result of this study provides insight for university top administration and faculty remembers about students' perception and utilization of technology, major challenges faced by students' and practice. However, the researcher was collected data from a small sample of students enrolls in undergraduate regular program at Haramaya University. The sample may not represent the whole population of Haramaya University students. Therefore, further researchers may want to validate this finding using students` of different universities in the country. The researcher measure only students perception and utilization of technology for learning, using self-report questionnaire as 
Online Journal of Communication and Media Technologies

Volume: 8 - Issue: 1 January - 2018

primary data collection instrument and do not examine the perception of teacher in comparative manner against students. Therefore, researcher suggested that, effectiveness of ICT integration for learning, distance education and technology oriented curriculum development and evaluation may be the area of research in the future. 


\section{Reference}

Adedeji, O.A. (2010). The Development of modern information and communications technology in Ibadan: Creative Educational Publication Ltd, p. 58.

Azhar, M., Nasir, H, B. \& Farah. N. (2011). Effects of use of ICT: students` perception at higher education level. Elixir Social Studies 38 (2011) 4118-4221.

Belal, A.R. (2011) "students` perception of computer Assisted Learning: an empirical study", Int. J. Management in Education, Vol.5, No.1.pp.63-78.

Buabeng, A \& Yidana, I. (2015). Innovation in education: Students` perception of implementing ICT in learning in second-cycle institution in Ghana: $7^{\text {th }}$ World Conferences on Educational Sciences, (WCES-2015), 05-07 February 2015, Novotel Athens Convention center, Athens, Greece. www. Sciencedirect.com. Retrieved from Elsevier, in 2017.

Cavas, B. and Cavas, P, (2009). A Study on Sciences Teachers`Attitudes towards and Communication Technology in Education: TOJET, 8(2), 20-32.

Christina, K., and Lars, C. (2002). Students Perception of E-learning in University Education. Journal of Educational Media, Vol. 27, Nos, 1-2, 2002.

Drop, J. (2004). Experience and attitudes towards information technology among first year medical students in Denmark: Longitudinal questionnaire survey. Journal of Medical Internet Research, 6 (1), e10.

Gay, L. R., \& Airasian, P. (2003). Educational Research: Competencies' for analysis and applications ( $7^{\text {th }}$ ed.). Upper Saddle River, NJ: Pearson Education.

Gay, G, Blads, R. (2005). Information Technology for CXC CSEC, Oxford University Press, UK.

GTP-II- (2015/16-2019/20). Growth and Transformation Plan II (GTP-II-). National Planning Commission, Vol. I. Main text. May 2016. Addis Ababa Ethiopia.

Hawkins, R.J. (2002). Ten lesson for ICT and education in the developing world. New York: Oxford University Press.

Kennewell, S. (2001). Using affordance and constraints to evaluate the use of information and communication technology in teaching and learning. Journal of Information Technology for Teacher Education, 10(1-2), 101-116.

Kozma, R.B. (2005). National policies that connect ICT- based education reform to economic and social development. An Interdisciplinary Journal on Humans in ICT Environment, 1(2), 117-156. 
Kubiatko, M., \& Halakova, Z. (2009). Slovak high school students' attitudes to ICT using in Biology lesson. Computer in Human Behavior, 25, 743-748.

Miranda, H., \& Russell, M. (2011). Predictors of teachers directed students' use of technology in elementary classrooms: A multilevel SEM approach using data from the USEIT study. Journal of Research on Technology in Education, 43(4), 301-323. Retrieved from EBSCO host.

Marc. L \& Mariana, D. (2014). ICT as an Enabler of Transformation in Ethiopian. www. world bank. org/ICT

Mizrachi, D., \& Shoham, S (2004). Computer attitudes and library anxiety among undergraduates: a study of Israel B. Ed students. International Information and Library Review, 36(2), 29-38.

Liu, P-L., Chen, C-J. and Chang, Y-J. (2010) "Effects of a computer-assisted concept mapping learning strategy on EFL college students” English reading comprehension, Computer \&Education, Vol.54, No.2, pp.436-445.

Selwyn, N. (2007) "The use of computer technology in university teaching and learning: a critical perspective", Journal of Computer Assisted Learning, Vol, 23, No, 2, pp.8394.

Seyal, A, H., Rahim, M, \&, N.A (2002). A study of computer attitudes of non-computing students of technical college in Burnei Darussalam. Journal of End User Computing, $14(2), 40-47$.

Thomas Li-Ping Tang, M. Jill Austin.(2009). Students' perception of teaching technologies, application of technologies, and academic performance. ELSEVIER. Computer \& Education 53(2009)1241-1255.

UNESCO. (2004).Use of Technology. Retrieved from: http://portal.unesco.org/education/en/ev.

William, M, L., Paprock, K., \& Covington, B. (1999). Distance learning. The essential guide (sage Publications, Thousand and Oaks). 